\title{
Unusual low plasma levels of zinc in non-pregnant Congolese women
}

\author{
Solo Kuvibidila ${ }^{1,2} *$ and Mbele $\mathrm{Vuvu}^{3}$ \\ ${ }^{1}$ Department of Nutritional Sciences, Oklahoma State University, 301 Human Environmental Sciences, Stillwater, OK 74078, USA \\ ${ }^{2}$ Department of Pediatrics, The Research Institute for Children's Hospital/Louisiana State University Health Sciences Center, \\ New Orleans, LA, USA \\ ${ }^{3}$ Nsundi-Lutete Hospital, Eglise du Christ au Congo B.P. 36, Luozi, Bas-Congo, Democratic Republic of Congo \\ (Received 17 March 2008 - Revised 2 October 2008 - Accepted 3 October 2008 - First published online 5 December 2008)
}

$\mathrm{Zn}$ is an essential trace element required throughout the life cycle. Although suboptimal $\mathrm{Zn}$ status is thought to be common in many sub-Saharan countries, there is a paucity of data in the Democratic Republic of Congo. The objective of the study was to determine $\mathrm{Zn}$ status in non-pregnant Congolese women. We measured plasma $\mathrm{Zn}$ and indicators of nutritional status (albumin, prealbumin, retinol-binding protein) and inflammation (C-reactive protein (CRP), ceruloplasmin, $\alpha 1$-acid glycoprotein (AGP)) in seventy-seven lactating and thirty non-lactating women (mean age 28 and 31 years, respectively). Blood samples were collected in summer 1989 in rural Bas-Congo during a survey on Fe status. Mean lactation period was 8.3 months. Mean parity was higher in lactating (3.6) than in non-lactating $(2 \cdot 2)$ women $(P<0.05)$. Mean biochemical indicators of nutritional status, CRP and ceruloplasmin were within normal range and not different between groups. Mean AGP concentrations were above normal $(>1.2 \mathrm{~g} / \mathrm{l})$ and higher in lactating $(1.365 \mathrm{~g} / \mathrm{l})$ than in non-lactating $(1.178 \mathrm{~g} / \mathrm{l})$ women $(P<0.05)$. Mean $\mathrm{Zn}$ concentration $(540 \mu \mathrm{g} / \mathrm{l})$ of the overall study population was below normal $(700 \mu \mathrm{g} / \mathrm{l})$; and the mean was lower in lactating $(455 \mu \mathrm{g} / \mathrm{l})$ than in non-lactating $(759 \mu \mathrm{g} / \mathrm{l}) \mathrm{women}(P<0 \cdot 05)$. Multiple regression analysis suggested that parity $(P<0.05)$, but not inflammation, was the most important factor associated with low $\mathrm{Zn}$ levels Despite the lack of data on dietary intake, the results suggest that suboptimal $\mathrm{Zn}$ status may be common in the studied population.

Zinc: Lactation: Inflammation: Democratic Republic of Congo

$\mathrm{Zn}$, an essential trace element involved in the metabolism of proteins, nucleic acids, lipids and carbohydrates, is required for immunity, growth and cognitive development of children ${ }^{(1-3)}$. The requirement of $\mathrm{Zn}$ is high during lactation because of secretion into milk ${ }^{(4-8)}$. In humans, although in general there is a poor correlation between maternal $\mathrm{Zn}$ status and milk $\mathrm{Zn}$ content, some animal studies suggest that maternal $\mathrm{Zn}$ supplementation may affect milk $\mathrm{Zn}$ levels ${ }^{(9)}$. A few human studies have also suggested that $\mathrm{Zn}$ supplementation during pregnancy and/or lactation was associated with a slower fall in milk $\mathrm{Zn}$ levels during lactation ${ }^{(1,4,10)}$.

Marginal $\mathrm{Zn}$ deficiency is thought to be very common in many developing countries because of inadequate dietary intake and poor bioavailability ${ }^{(2-3)}$. In sub-Saharan Africa, it is estimated that $68 \%$ of the population is at risk of low $\mathrm{Zn}$ intake and therefore at risk of moderate $\mathrm{Zn}$ deficiency ${ }^{(2)}$. The diet of many Congolese individuals is composed of various vegetables, legumes such as beans and peas, and tubers and therefore is rich in phytates. Cassava, the staple food in the Democratic Republic of Congo (DR Congo), is relatively rich in $\mathrm{Zn}$ content (2.33$6.93 \mathrm{mg} / 100 \mathrm{~g})$ compared with rice $(1.60-1.73 \mathrm{mg} / 100 \mathrm{~g})$, banana plantains $(1.35-4.46 \mathrm{mg} / 100 \mathrm{~g})$ and groundnuts $(2.46-$ $2.95 \mathrm{mg} / 100 \mathrm{~g})^{(11)}$. However, because of the high phytate content $(355-530 \mathrm{mg} / 100 \mathrm{~g}), \mathrm{Zn}$ bioavailability is limited ${ }^{(12)}$.
Meat and fish intake of individuals who live in rural areas is limited.

Although marginal Zn status is expected in the DR Congo because of its geographical location, there is a paucity of data in Congolese lactating women. Considering the type of diet and the presence of factors that interfere with $\mathrm{Zn}$ metabolism, we hypothesise that marginal $\mathrm{Zn}$ status is common in women of reproductive age. The goal of the present cross-sectional preliminary study was to determine plasma $\mathrm{Zn}$ levels in non-pregnant Congolese women, especially lactating women, and whether low plasma $\mathrm{Zn}$, if any, is due to inflammation.

\section{Materials and methods \\ Study population, blood drawing and laboratory measurements}

The 107 women included in the present study (seventy-seven lactating and thirty non-lactating women) were a part of a group of 213 non-pregnant women and their young children (aged 0-5 years) who were recruited in summer 1986 and 1989 for evaluation of $\mathrm{Fe}$ status and inflammation in the rural Bas-Congo state in the DR Congo. Conditions under which the blood samples were drawn and measurements of

Abbreviations: AGP, $\alpha 1$-acid glycoprotein; APP, acute-phase protein; CER, ceruloplasmin; CRP, C-reactive protein; DR Congo, Democratic Republic of Congo. *Corresponding author: Dr Solo Kuvibidila, fax +1 405744 1357, email solo.kuvibidila10@okstate.edu 
acute-phase proteins (APP) (C-reactive protein (CRP), $\alpha 1$-acid glycoprotein (AGP) and ceruloplasmin (CER)) and biochemical indicators of nutritional status (albumin, prealbumin, transferrin and retinol-binding protein) have been previously published ${ }^{(13,14)}$. Inflammation was defined by the following cut-off points: AGP $>1.2 \mathrm{~g} / \mathrm{l}$, CRP $>10 \mathrm{mg} / \mathrm{l}$ and CER $>500 \mathrm{mg} / \mathrm{l}^{(15)}$. The following cut-off points were used to define abnormal biochemical indicators of nutritional status: albumin $<35 \mathrm{~g} / \mathrm{l}$, prealbumin $<160 \mathrm{mg} / \mathrm{l}$, retinol-binding protein $<30 \mathrm{mg} / \mathrm{l}$ and $\mathrm{Zn}<700 \mu \mathrm{g} / \mathrm{l}^{(16)}$.

Inclusion criteria in the present study were: (1) availability of plasma for measurement of $\mathrm{Zn}$ (by atomic absorption spectrophotometer (model 3030B; Perkin Elmer; Norwalk, CT, USA)); (2) data on any two APP and any three biochemical indicators of nutritional status; (3) no recent major illness requiring surgery and/or hospitalisation; (4) non-pregnant woman aged 15-50 years, resident in the Nsundi-Lutete area. Weight and height were measured in seventy-eight women and BMI was calculated by the standard formula $\left(\mathrm{kg} / \mathrm{m}^{2}\right)$. Information on parity was collected by interview in seventy-four women at the time of blood drawing. No information was collected on $\mathrm{Zn}$ intake, and $\mathrm{Zn}$ supplementation is uncommon in the DR Congo. All women lived on farming and none had education above high school, had electricity and/ or running water at home. The study was approved by the Investigation Review Board of Louisiana State University Health Sciences Center (New Orleans) and the NsundiLutete Hospital (DR Congo). Personal consent was obtained before enrolling the women in the study.

\section{Statistical analysis}

Descriptive statistics (mean values and standard deviations), one-way ANOVA and Student's $t$ test were performed by Microstatistical program (Microsoft Inc., Indianapolis, IN, USA). Multiple regression analysis with age, parity, biochemical indicators of nutritional status and APP as independent variables, and plasma $\mathrm{Zn}$ as the dependent variable, and Pearson correlation were also performed. The level of significance was set at $P<0 \cdot 05$.

\section{Results}

\section{General information and nutritional status}

The range, mean and median duration of lactation, which corresponded to the age of lactating women's infants, were $0.25-25,8.3$ and 7 months, respectively. The range, mean and median age of non-lactating women's children were 9$30,19.38$ and 22 months, respectively. Parity ranged from 1 to 10 with a median of 3 for lactating women and from 1 to 4 with a median of 2 for non-lactating women, respectively. Mean parity was higher in lactating than in non-lactating women $(P<0.05)$. There were no significant differences regarding age between lactating and non-lactating women.

Based on the concentration of plasma proteins, in general, the studied women had adequate nutritional status, and the means of the various measurements were not statistically different between both study groups (Table 1). However, $11 \cdot 8,10$ and $26 \%$ of lactating women had albumin, prealbumin and retinol-binding protein below normal, respectively. The corresponding values for non-lactating women were $16,9.7$ and $22.6 \%$. Mean BMI was significantly lower in non-lactating than in lactating women $(P<0.05)$.

\section{Acute-phase proteins}

Mean AGP concentrations were significantly higher in lactating than in non-lactating women (Table $1 ; P<0.05$ ) and those of CRP and CER were not different. While the mean CRP and CER concentrations were within the normal range, those of AGP were above normal $(>1.2 \mathrm{~g} / \mathrm{l})$ in lactating, but not in non-lactating women. A higher percentage of lactating

Table 1. General characteristics and nutritional status of the study population

(Mean values and standard deviations)

\begin{tabular}{|c|c|c|c|c|c|c|}
\hline & \multicolumn{2}{|c|}{$\begin{array}{l}\text { All women } \\
\quad(n \text { 107) }\end{array}$} & \multicolumn{2}{|c|}{$\begin{array}{l}\text { Lactating women } \\
\qquad(n 77)\end{array}$} & \multicolumn{2}{|c|}{$\begin{array}{l}\text { Non-lactating women } \\
(n \text { } 30)\end{array}$} \\
\hline & Mean & SD & Mean & SD & Mean & SD \\
\hline Age (years) $†$ & $29 \cdot 2$ & $8 \cdot 10$ & 28.30 & 7.40 & $31 \cdot 10$ & $9 \cdot 30$ \\
\hline Parity $¥$ & 3.35 & $2 \cdot 24$ & 3.59 & $2 \cdot 37$ & $2 \cdot 23^{*}$ & 0.93 \\
\hline Weight $(\mathrm{kg}) \S$ & 62.91 & $11 \cdot 82$ & 65.59 & $8 \cdot 61$ & $58 \cdot 54$ & $15 \cdot 60$ \\
\hline Height $(\mathrm{cm}) \S$ & 153.46 & 0.74 & 152.99 & 0.96 & $154 \cdot 60$ & 5.59 \\
\hline BMI $\left(\mathrm{kg} / \mathrm{m}^{2}\right) \S$ & 27.65 & $6 \cdot 86$ & 29.12 & 5.94 & $25 \cdot 12^{*}$ & $7 \cdot 72$ \\
\hline Albumin (g/l) & 45.99 & 75.5 & 45.91 & 1.02 & $46 \cdot 02$ & 1.72 \\
\hline Prealbumin (mg/l) & 252.4 & $7 \cdot 24$ & 248.79 & 74 & 261.60 & $79 \cdot 1$ \\
\hline Retinol-binding protein $(\mathrm{mg} / \mathrm{l})$ & 35.05 & 1.00 & 34.09 & $10 \cdot 00$ & 37.27 & 11.46 \\
\hline Transferrin $(\mathrm{g} / \mathrm{l})$ & 3.21 & 0.56 & $3 \cdot 17$ & $5 \cdot 51$ & 3.31 & 0.12 \\
\hline$\alpha-1$-Acid glycoprotein (g/l) & 1.31 & 0.49 & 1.37 & 0.44 & $1 \cdot 18^{*}$ & 0.65 \\
\hline C-reactive protein (mg/l) & $6 \cdot 96$ & $1 \cdot 12$ & $7 \cdot 90$ & $13 \cdot 65$ & $4 \cdot 27$ & 0.217 \\
\hline Ceruloplasmin (mg/l) & 492.83 & 14.87 & 494 & 155 & 484.90 & $151 \cdot 70$ \\
\hline
\end{tabular}

* Mean value was significantly different from that of the lactating women $(P<0.05)$.

†For age, the sample sizes were 82,52 and 30 for the overall study population, lactating women and non-lactating women, respectively. Age could not be confirmed in twenty-five lactating women because of lack of identification.

ҒFor parity, the sample sizes were 74,61 and 13 for the overall study population, lactating women and non-lactating women, respectively.

$\S$ For weight, height and BMI, the sample sizes were 78,52 and 26 for the overall study population, lactating women and non-lactating women, respectively. 
women than of non-lactating women had AGP levels above normal (64.9 v. 38.7\%; $\left.\chi^{2} 5.588 ; P=0.01\right)$ and CRP above normal $\left(16.9\right.$ v. $\left.3.3 \%, \chi^{2} 3.485 ; P<0.05\right)$. CER concentration was above normal in $35 \%$ lactating and $38.7 \%$ of non-lactating women. Approximately $33 \%$ of lactating women and $13 \%$ of non-lactating women had two to three APP concentrations suggestive of inflammation.

\section{Plasma zinc}

Mean $\mathrm{Zn}$ levels of lactating women were significantly lower than those of non-lactating women; in general, differences between both groups persisted after taking into account inflammation (Table $2 ; P<0.05)$. In the group of lactating women, although those with inflammation tended to have lower mean plasma $\mathrm{Zn}$ levels than those without inflammation, the differences were not significant. The same trend was observed with non-lactating women without and those with inflammation. Approximately $78 \%$ of the overall study population had $\mathrm{Zn}$ levels below $700 \mathrm{~g} / \mathrm{l}$. As expected, the percentage of women in the overall population with Zn levels $<700 \mu \mathrm{g} / \mathrm{l}$ increased with the number of APP in the levels suggestive of inflammation $(72 \%$ (18/25), $83 \%$ (44/53), $83 \%(20 / 24)$ and $100 \%$ (5/5) for no, one, two and three APP above normal, respectively).

Plasma $\mathrm{Zn}$ poorly correlated with indicators of nutritional status, APP and age ( $r 0.03$ to $0.1495 ; P>0.05)$. However, in women in whom parity was known, albumin ( $r$ 0.312) and parity $(r-0 \cdot 278)$ were significantly correlated with plasma $\mathrm{Zn}(P<0 \cdot 05)$. Multiple regression analysis suggested that parity was the most important variable that was negatively and significantly associated with low plasma $\mathrm{Zn}(P<0.05)$. Albumin $(P=0.026)$ and prealbumin $(P=0.021)$ also had some predictive effect on plasma $\mathrm{Zn}$. In contrast to indicators of nutritional status, no single APP had a significant association with plasma Zn levels.

\section{Discussion}

Plasma $\mathrm{Zn}$ is the most commonly used index of $\mathrm{Zn}$ status at the population levels ${ }^{(17)}$. Although it represents only $0.1 \%$ of the total body pool, and $12-22 \%$ of the overall blood pool, it is sensitive to dietary depletion ${ }^{(3)}$. Unfortunately, plasma $\mathrm{Zn}$ levels below $700 \mu \mathrm{g} / \mathrm{l}$ are not always indicative of suboptimal status since values can also decrease following infections, inflammation and trauma, in part because of body redistribution $^{(3,18)}$. The mean plasma $\mathrm{Zn}$ levels of the overall study population and lactating women are below normal for published standards for healthy adults from Western countries $^{(3,17)}$. However, they are not very different from those that have been reported in women from other African countries ${ }^{(19,20)}$. Additionally, they are similar to those reported for pregnant women ${ }^{(21)}$.

There are several possible causes of low plasma $\mathrm{Zn}$ levels in the studied population: dietary intake, Zn bioavailability, acute and/or chronic inflammation, infection, diurnal variations, use of oestrogen-containing compounds such as oral contraceptives, and hypoalbuminaemia ${ }^{(3)}$. All blood samples were drawn between 09.00 and 12.00 hours; therefore diurnal variation cannot explain the low levels in the studied population. Although information on oral contraceptive use was not collected, the practice is very uncommon because of availability and cost. Although inflammation may have some influence on low plasma $\mathrm{Zn}$ levels, it does not fully explain the suboptimal status (Table 2). Low plasma Zn levels were not due to hypoalbuminaemia because mean plasma $\mathrm{Zn}$ levels of thirteen women with albumin levels below normal (469 (SD 204) $\mu \mathrm{g} / \mathrm{l}$ ) were not lower than those of women with normal levels (524 (SD 356) $\mu \mathrm{g} / \mathrm{l}$ ). We therefore speculate that low plasma $\mathrm{Zn}$ levels in the studied women are due to inadequate intake and/or bioavailability due to factors such as phytates that are common in cassava and other foods usually consumed by Congolese.

The negative association between parity and plasma $\mathrm{Zn}$ levels suggests that the cycle of frequent pregnancies and lactation very probably contributes to the low plasma $\mathrm{Zn}$ levels in the studied population. Normally, Zn absorption increases during lactation; however, this adaptation alone may not be enough to maintain $\mathrm{Zn}$ homeostasis ${ }^{(6,22)}$. Despite the limited sample size, lack of information on dietary intake and/or other indices of $\mathrm{Zn}$ status, our preliminary data suggest that suboptimal $\mathrm{Zn}$ status may be very common in the studied population and that elevated

Table 2. Plasma zinc levels $(\mu \mathrm{g} / \mathrm{l})$ in women without and with inflammation (Mean values and standard deviations)

\begin{tabular}{|c|c|c|c|c|c|c|c|c|c|}
\hline & \multicolumn{3}{|c|}{ All women } & \multicolumn{3}{|c|}{ Lactating women } & \multicolumn{3}{|c|}{ Non-lactating women } \\
\hline & $n$ & Mean & SD & $n$ & Mean & SD & $n$ & Mean & SD \\
\hline All women & 107 & 540 & 398 & 77 & 455 & 203 & 30 & $759^{\star}$ & 634 \\
\hline Women with Zn < 700 $\mu \mathrm{g} / \mathrm{l}(\%)$ & 83 & \multicolumn{2}{|c|}{$77 \cdot 6$} & 65 & \multicolumn{2}{|c|}{84.4} & 18 & \multicolumn{2}{|c|}{60.0} \\
\hline$A G P \leq 1.2 \mathrm{~g} / \mathrm{l}$ & 45 & 581 & 467 & 27 & 446 & 165 & 18 & $785^{\star}$ & 671 \\
\hline $\mathrm{AGP}>1.2 \mathrm{~g} / \mathrm{l}$ & 62 & 510 & 341 & 50 & 460 & 224 & 12 & $720^{\star}$ & 601 \\
\hline $\mathrm{CRP} \leq 10 \mathrm{mg} / \mathrm{l}$ & 93 & 554 & 418 & 64 & 458 & 203 & 29 & $767^{\star}$ & 640 \\
\hline $\mathrm{CRP}>10 \mathrm{mg} / \mathrm{l}$ & 14 & 447 & 210 & 13 & 440 & 217 & 1 & 533 & 0 \\
\hline $\mathrm{CER} \leq 500 \mathrm{mg} / \mathrm{l}$ & 69 & 566 & 395 & 49 & 480 & 223 & 16 & $797^{\star}$ & 614 \\
\hline $\mathrm{CER}>500 \mathrm{mg} / \mathrm{l}$ & 38 & 494 & 406 & 27 & 413 & 161 & 14 & $693^{*}$ & 693 \\
\hline \multicolumn{10}{|l|}{$\begin{array}{l}\text { Number of acute-phase proteins } \\
\text { above normal } \dagger\end{array}$} \\
\hline None & 25 & 613 & 413 & 15 & 497 & 174 & 10 & $788^{*}$ & 593 \\
\hline One & 53 & 563 & 463 & 37 & 450 & 218 & 16 & $823^{\star}$ & 726 \\
\hline Two to three & 29 & 436 & 197 & 25 & 437 & 208 & 4 & 429 & 174 \\
\hline
\end{tabular}

AGP, $\alpha$-1-acid glycoprotein; CRP, C-reactive protein; CER, ceruloplasmin.

* Mean value was significantly different from that of the lactating women $(P<0.05)$.

† As defined in Materials and methods. 
plasma levels of APP and/or hypoalbuminaemia do not explain the suboptimal $\mathrm{Zn}$ status. Given the importance of $\mathrm{Zn}$ in health, specifically immunity, cognition and physical development of children, and pregnancy outcome, more studies should be conducted in this population.

\section{Acknowledgements}

The present study was supported by Nestlé grant no. 85/45 and general funds from the Department of Pediatrics, Louisiana State University Health Sciences Center (New Orleans), the Research Institute for Children's Hospital in New Orleans and Oklahoma State University (Stillwater, OK, USA).

S. K. designed the study, participated in blood drawing, measured biochemical indicators of inflammation and plasma $\mathrm{Zn}$, analysed data and wrote the manuscript. The senior author M. V., a physician at Nsundi-Lutete Hospital, coordinated subject recruitment.

The authors thank all nurses who assisted in blood drawing and collection of demographic data, women who participated in the study and Carole Lachney for her technical assistance during the preparation of this paper.

There is no conflict of interest to declare.

\section{References}

1. Black RE (2001) Zinc deficiency, immune function, and morbidity and mortality from infectious disease among children in developing countries. Food Nutr Bull 22, 155-162.

2. Brown KH, Wuehler SE \& Peerson JM (2001) The importance of zinc in human nutrition and estimation of global prevalence of zinc deficiency. Food Nutr Bull 22, 113-125.

3. Gibson RS (2005) Assessment of chromium, copper and zinc status. In Principles of Nutritional Assessment, 2nd ed. pp. 711-731 [RS Gibson, editor]. New York: Oxford University Press.

4. Khosravi H, Galali BA \& Efekhari MH (2006) Effects of dietary zinc supplement during lactation on longitudinal changes in plasma and milk zinc concentrations. Nutrition 16, 71-75.

5. Karra M, Kirksey A, Galal O, et al. (1988) Zinc, calcium, and magnesium concentrations in milk from American and Egyptian women throughout the first 6 months of lactation. Am J Clin Nutr 47, 642-648.

6. Krebs N (1998) Zinc supplementation during lactation. Am J Clin Nutr 68, Suppl., 509S-512S.
7. Moser PB \& Reynolds RD (1983) Dietary zinc intake and zinc concentrations of plasma, erythrocytes, and breast milk in antepartum and postpartum lactating and non-lactating women: a longitudinal study. Am J Clin Nutr 38, 101-108.

8. Shaaban SY, El-Hodhod MAA, Nassar MF, et al. (2005) Zinc status of lactating Egyptian mothers and their infants: effect of maternal zinc supplementation. Nutr Res 25, 45-53.

9. Mutch PB \& Hurley LS (1974) Effects of zinc deficiency during lactation on postnatal growth and development of rats. $J$ Nutr 104, 828-842.

10. Aremu CY (1988) Chemical estimation of iron, zinc, copper, and phytatic acid in selected foodstuffs. Food Chem 27, 77-82.

11. Adeyeye EI, Arogundade LA, Akintayo ET, et al. (2000) Calcium, zinc, and phytate interrelationships in some foods of the major consumption in Nigeria. Food Chem 71, 435-441.

12. Lonnerdal B (2000) Dietary factors influencing zinc absorption. J Nutr 130, 1378S-1383S.

13. Kuvibidila S, Warrier RP, Yu L, et al. (1994) Reference levels of acute phase reactant proteins in healthy Zairean women in the reproductive age group. J Trop Med Hyg 97, 239-243.

14. Kuvibidila S, Yu L, Warrier RP, et al. (1994) Usefulness of serum ferritin levels in the assessment of iron status in nonpregnant Zarian women of childbearing age. J Trop Med Hyg 97, 171-179.

15. Engler R (1984) Bases méthodologiques: protéines de la réaction inflammatoire. Notion du profil protéique (Inflammatory reaction proteins. Concept of the protein profile). Pédiatrie 39, 339-344.

16. Haider M \& Haider SQ (1984) Assessment of protein-energy malnutrition. Clin Chem 30, 1286-1299.

17. Sandström B (2001) Diagnosis of zinc deficiency and excess in individuals and populations. Food Nutr Bull 22, 133-137.

18. Gaete LM, McClain CJ, Talwaljkar RT, et al. (1997) Effects of endotoxin on zinc metabolism in human volunteers. Am J Physiol 272, E952-E956.

19. Mbofung CMF \& Atinmo T (1985) Zinc, copper and iron concentrations in the plasma and diets of lactating Nigerian women. Br J Nutr 53, 427-439.

20. Yan L, Prentice A, Dibba B, et al. (1996) The effect of longterm calcium supplementation on indices of iron, zinc, and magnesium status in lactating Gambian women. $\mathrm{Br} J$ Nutr 76, 821-831.

21. Maia PA, Figueiredo C \& Anastacio AS (2007) Zinc and copper metabolism in pregnancy and lactation of adolescent women. Nutrition 23, 248-253.

22. King JC (2002) Enhanced zinc utilization during lactation may reduce maternal and infant zinc depletion. Am J Clin Nutr 75, 2-3. 